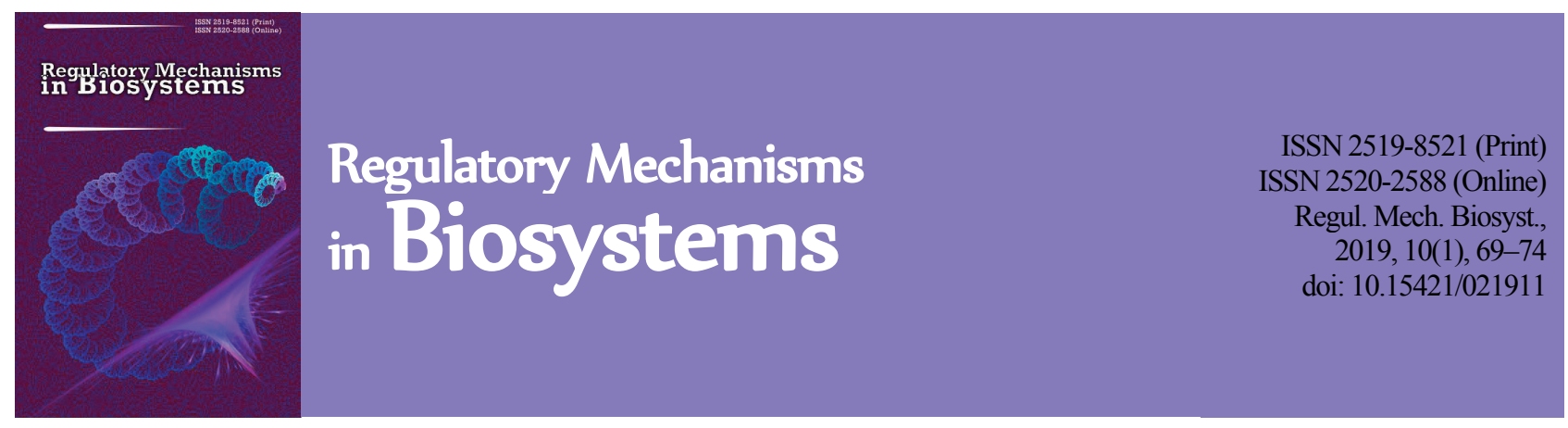

\title{
Pathomorphological changes in the large intestine of rabbits parasitised by Passalurus ambiguus (Nematoda, Oxyuridae)
}

\author{
S. M. Mykhailiutenko*, O. V. Kruchynenko*, O. S. Klymenko*, \\ J. K. Serdioucov**, N. I. Dmytrenko*, V. V. Tkachenko** \\ *Poltava State Agrarian Academy, Poltava, Ukraine \\ **National University of Life and Environmental Sciences of Ukraine, Kyiv, Ukraine
}

Article info

Received 19.01.2019

Received in revised form 25.02.2019

Accepted 27.02.2019

Poltava State Agrarian Academy, Skovorody st., 1/3, Poltava, 36003, Ukraine.

National University of Life and Environmental Sciences of Ukrain Heroiv Oborony st., 15 building 3 , Kyiv, 03041, Ukraine

Tel.: +38-099-062-64-96. E-mail: oleg.kruchynenko@pdaa.edu.ua

Introduction

Diseases caused by protozoans and helminths are classified as invasive or parasitic diseases (Ola-Fadunsin \& Ibitoye, 2017). Pathogens of these diseases have evolutionally adapted to parasitizing in the organism of animals and people. Pathological processes recorded in the course of parasitic diseases occur under the effect of certain factors (Pehlivanoğlu et al., 2016), including: condition of the animals, specific virulent effect of the parasites; capacity for adaptation, a certain competitiveness due to quick tempi of breeding; presence of factors which condition manifestation of the pathogenic properties of the parasites, species of animals, breed, type of feeding and maintenance (Zon, 2005; Emerya et al, 2016).

The organism of animals reacts to introduction of pathogens by a complex of pathophysiological and immunomorphological reactions. Protective forces of the organism are orientated to elimination of the pathogen and repair of structural and functional damage incurred during the infestation. The character of impact of parasites on the host organism of is extremely broad, and the same parasite can often act in different ways. According to the extent of the effect on the host, parasites are divided into more pathogenic and less pathogenic parasites. For this characteristic, notions of virulence are used. As we know, the extent of pathogenicity depends on the intensity of infestation (Eira et al., 2007; Edwards et al., 2016).

Any disease of infectious as well as non-infectious etiology causes damage to the internal organs and the systems of the organism. For determination of the impact of a pathogen on living animals, clinical and laboratory studies are conducted (Lello et al., 2005). In turn, pathoanatomical autopsy makes it possible to identify macroscopically manifested changes of the internal organs and the tissues. Pathomorphological assessment also allows analysis of the character of changes of damaged organs/tissues at the histological level. As a result of the undertaken experiment, one can develop objective orientations of treatment against parasitoids (Laakkonen et al., 2006; Jabbar et al., 2013).

Numerous publications indicate the distribution of invasive diseases of wild and domestic rabbits (Bordes et al., 2007; Sürsal et al., 2014; Okumu et al., 2014). It was proved that they can be infested by a number of parasites: helminths, protozoans and ectoparasites (FernándezAguilar et al., 2013; Ola-Fadunsin et al., 2018). According to Ilić et al. (2018), infestation of rabbits with parasites in Serbia equaled 82.7\%. 
Endoparasites (Eimeria spp., Trichostrongylus spp. and Passalurus ambiguns) and three species of ectoparasites (Acari of Sarcoptes, Psoroptes and Notoedres) were found. The authors emphasize that the young animals suffered coccidiosis $(50.6 \%)$ to a higher extent, and the older age group - trichostrongyliasis (39.1\%). According to other scientists, the parasitofauna of rabbits is represented by Eimeria (78.8\%), nematodes (16.4\%) and cestodes (5.5\%) (Szkucik et al., 2014).

Among parasitoses of rabbits, passaluriasis occupies a significant place. The disease is caused by Passalurus ambiguns, a rounded helminth of the Oxyuridae family, which parasitizes the large intestine (Georgieva et al., 2005). In rabbits aged up to one year, extensity of infestation equaled $5.8 \%$, which increased in the adults to $23.3 \%$ (Ilić et al., 2018). These rabbits were observed to have decrease in appetite. Active movements of female pathogens in the large intestine and irritation of the receptors in the area of the anal aperture lead to overexcitement of the nervous system, and, as a result, cause itch and scratches. In the area of the anus, inflammatory processes are diagnosed. At the same time, disorders in the digestive processes occur, causing loss of weight of the animals. High intensity of infestation can cause death (Florian, 1997; Rewatkar et al., 2013; Eslampanah et al., 2014).

The objective of the study was to research pathomorphological changes in the large intestine of rabbits with passaluriasis and determine the peculiarities of morphofunctional changes in the tissues of animals with a chronic course of the disease. For achieving this, we set ourselves the following tasks: to conduct pathoanatomical autopsy of rabbits with passaluriasis, and to study macroscopic and microscopic changes in the intestine of animals with this disease, because there is only a limited number of publications on the pathomorphology of this disease.

\section{Materials and methods}

The study was carried out during 2017-2018 at the premises of the Department of Anatomy, Histology and Pathomorphology of Animals named after V. H. Kasianenko (National University of Life and Environmental Sciences of Ukraine) and the scientific laboratory of the Department of Parasitology and Veterinary-Sanitary Expertise (Poltava National Agrarian Academy). All manipulations with the animals in the experiment were conducted with correspondence to the ethical norms, and therefore to the international and Ukrainian legislations. The rabbits were maintained in individual farmyards of Poltava Oblast. The material for the study was the large intestine of compulsorily slaughtered seryi veleten rabbits, taken from 5 males and 5 females.

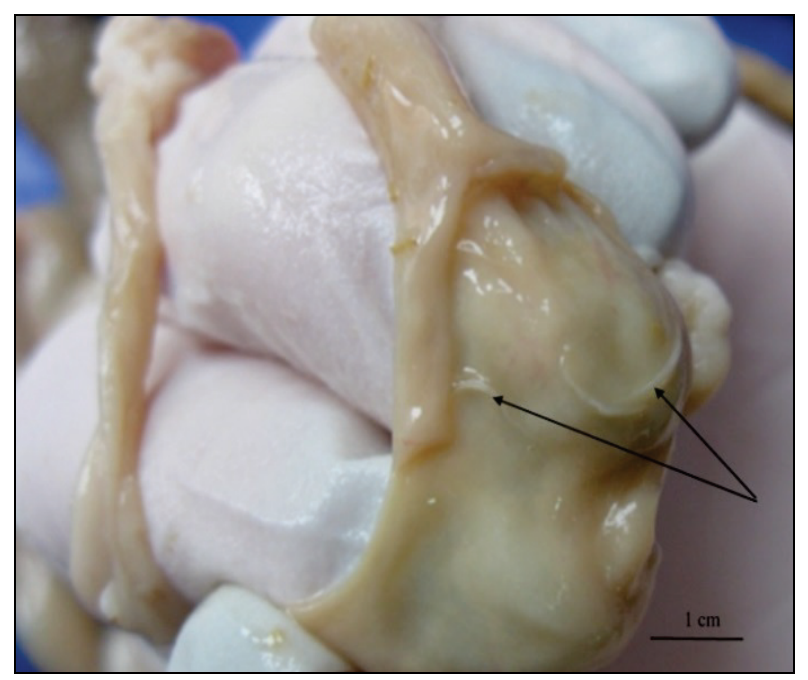

Fig. 1. Passalurus ambiguus on the mucous membrane of the large intestine: $\mathrm{bar}-1 \mathrm{~cm}$

Pathoanatomical autopsy was conducted using the method of complete helminthological dissection of separate organs according to K. I. Skriabin's method (Goral's'kyj et al., 2005; Zon, 2005). The selected sections were fixated in $10 \%$ neutral solution of formalin. Histosections were prepared according to classic method in NM-440E (Russian - HM-
440E) sledge microtome, stained used Carazzi's hematoxylin and eosin. Microphotographs were taken using a micros mcq 2000 light binocular microscope with system of analysis of image using Video Test program. General structure, appearance of the tissue, and specific morphological changes were examined at ${ }^{\mathrm{x}} 100,{ }^{\mathrm{x}} 400$ magnifications.

After anatomical dissection of the large intestine, 846 nematodes (369 males and 477 females) were extracted for determining macrometric and metric parameters. The species of helminth was identified using the guide by Gvozdev et al. (1970). The specimens were examined and identified using the light microscope Zeiss Axio Imager M1 at I. I. Schmalhausen Institute of Zoology (Kyiv, Ukraine).

Statistical-mathematic analysis of the obtained results of the research was conducted on a personal computer using Statistica 10 program (StatSoft Inc., USA, 2011). The parameters were expressed as an average arithmetic value $\pm \mathrm{SD}$ (standard deviation). For comparison of morphometric parameters of length and width of body of males and females of Passalurus ambiguus, we used the Mann-Whitney U test. For comparing number of males and females in one organism of infested rabbits, we used the Willcoxon criterion. The differences between the parameters in the groups were considered significant at $\mathrm{P}<0.05$.

\section{Results}

During dissection of the rabbits (Oryctolagus cuniculus), we found small, spindle-like white helminths in the cavity of the large intestine (Fig. 1). According to the results of parasitological studies, the nematodes isolated from the animals were identified as $P$. ambiguus. In male rabbits, the number of collected helminths ranged within 46 to 105 specimens, against 68-142 for females.

While measuring the females and males of $P$. ambiguus in rabbits of different sexes, we determined their different ratio on average (Fig. 2).

It was determined that nematodes are characterized by a specific morphological structure. Accordingly, the common feature for mature males and females of the species was the presence of a rounded enlargement (bulbus) at the end of the esophagus. At the same time, the head end had narrow lateral wings and a simple mouth with a small mouth capsule (Fig. 3a). In morphological structure, nematode females have a well-developed ovijector, in which elongated oval asymmetric eggs are concentrated (Fig. 3b). The vulva is in the anterior part of the body. The tail process of females is narrow and long with ring-like thickenings of the cuticle (Fig. 4b). Imago forms of the male nematodes are characterized by the following morphological species features: peculiarity of the shape, presence of one spicule (Fig. 4a).

We determined the main metric parameters of the P. ambiguus specimens of seryi veleten breed rabbits in Poltava Oblast (Ukraine), which allowed us to update the information on species features of mature helminths (Table 1). The results of the studies revealed that parameters of length and width of the body of females of $P$. ambiguus reliably differed from the males $(\mathrm{P}<0.001)$. The variation coefficient, according to the data in the tables, indicates that the selection had low and average extent of variability.

We also macroscopically determined the average level and belowaverage level of the nutrition state of the rabbits. For all cases, tympanites was characteristic. The wall of the large intestine on the side of the serous membrane in all animals had a non-uniform pink-reddish colour and blood saturation of the vessels, and slightly differed by extent of pathological changes depending on the section of the animal's intestine. The mucous membrane of the large intestine was not thickened, bore small amount of dark viscous slime on its surface. The wall of the large intestine was thickened, the mucous membrane was pale. We found singular rounded bleeding holes and numerous helminths.

Dissecting the rabbits, we observed changes in the large intestine. The upper epithelium of the large intestine was destroyed in some parts, some epithelial cells were present in the lumen of the intestine (Fig. 5).

The intestinal glands were widened, filled with slimy content which became stained mostly in dark blue-violet colour (Fig. 6-8), especially in the upper sections of the glands, i.e. had basophilic colour. In deep sections of the glands, the slime was almost transparent. In the epithelial cells of the glands, slimy granules were also mostly of basophilic colour (Fig. 8). 

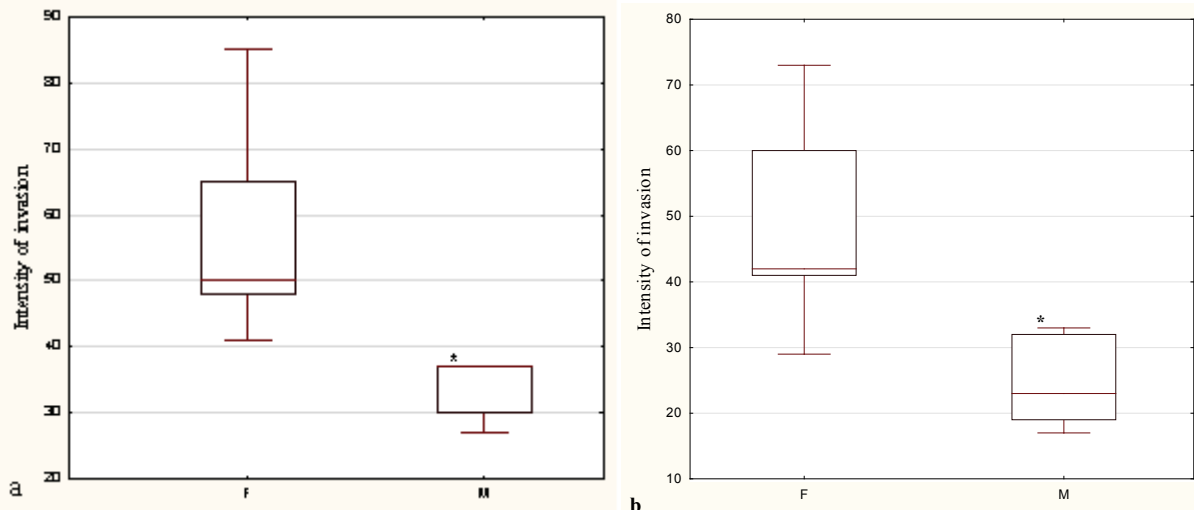

Fig. 2. The number of $q(\mathrm{~F})$ and $\widehat{\partial}(\mathrm{M})$ Passalurus ambiguus: $a$ - in male rabbits; $b$ - in female rabbits, Me (Q1;Q3); * $-\mathrm{P}<0.05$

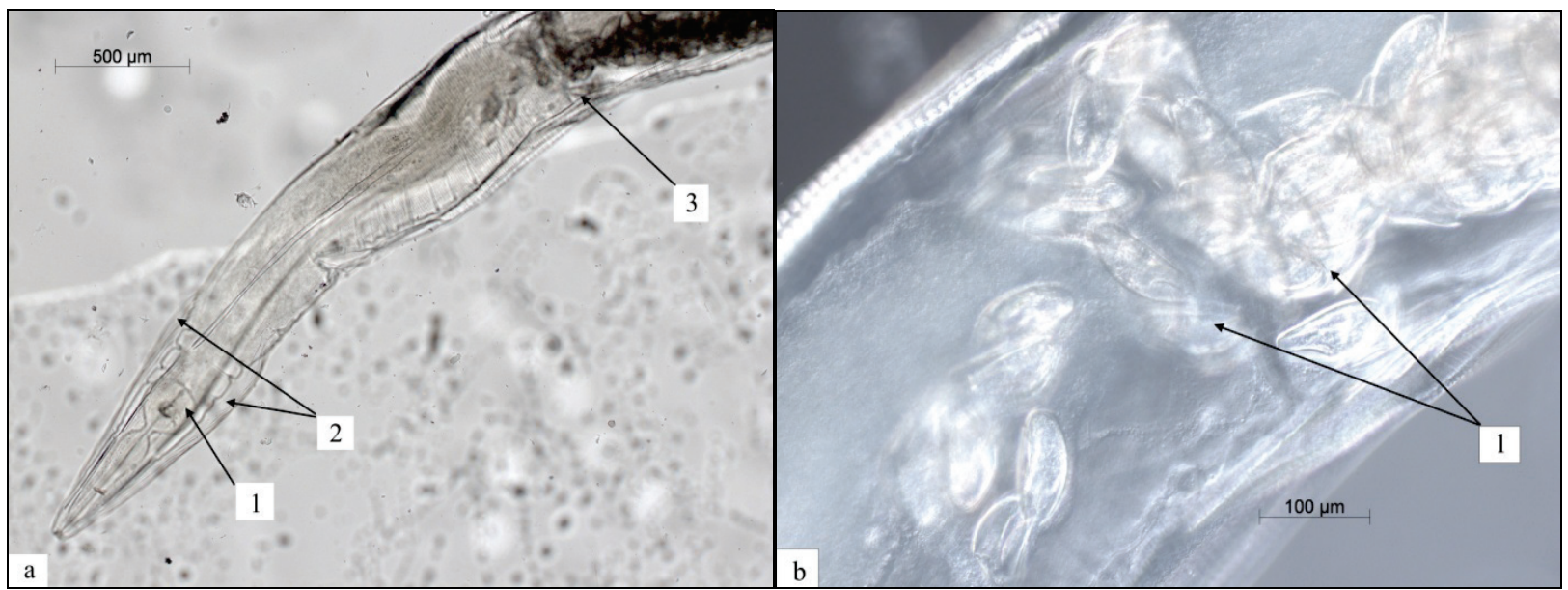

Fig. 3. Morphological structure of female Passalurus ambiguus:

$a$ - anterior end, $1 a$ - bulbus, $2 a$ - lateral wings, $3 a$ - area of the vulva; $1 b$ - eggs in the cavity of the uterus

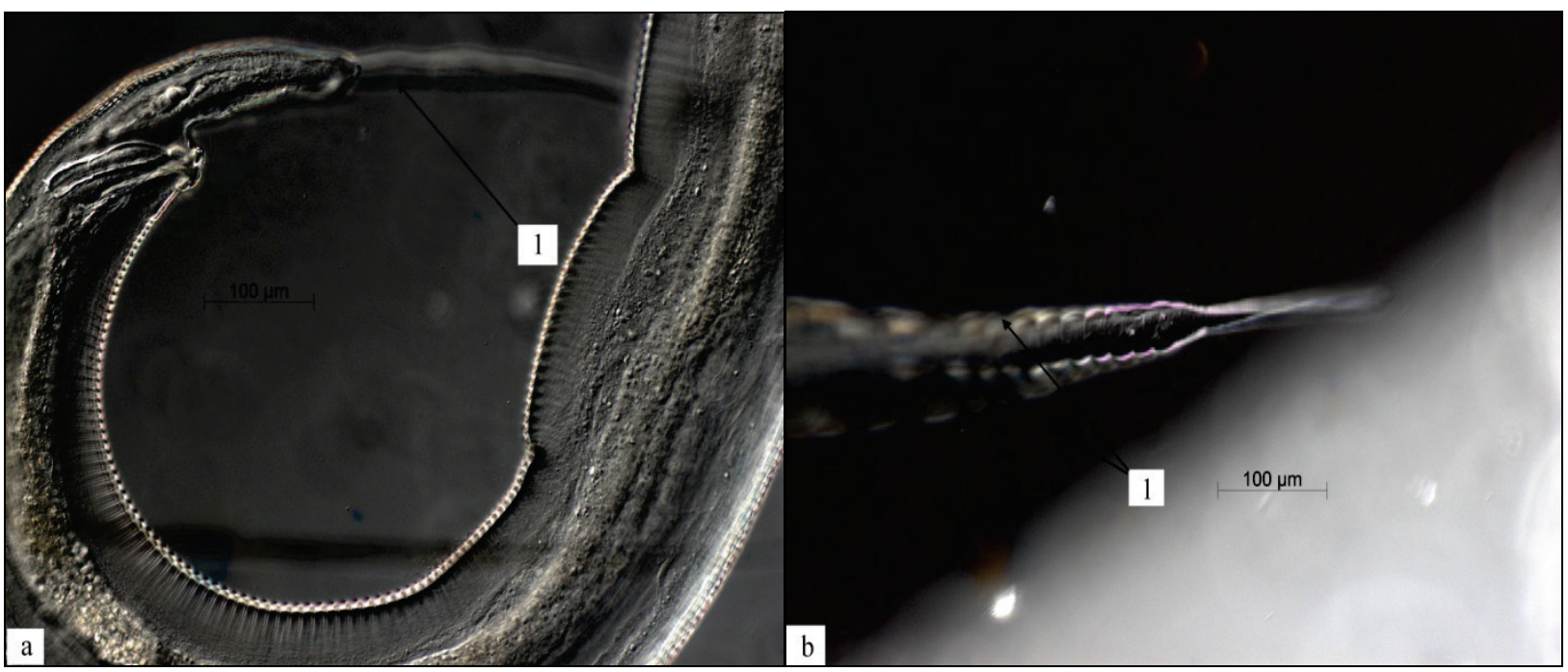

Fig. 4. Tail end of Passalurus ambiguus: $1 a$-spicule $(\overbrace{}^{\Uparrow}), 1 b$ - ring-like thickenings of the cuticle (ㅇ)

Table 1

Metrical species parameters of Passalurus ambiguus, Isolated from rabbits $(\mathrm{n}=20)$

\begin{tabular}{lcccccc}
\hline \multicolumn{1}{c}{ Parameter } & \multicolumn{3}{c}{ Sizes of ${ }^{\lambda}$} & & \multicolumn{3}{c}{ Sizes of $q$} \\
\cline { 2 - 7 } & $\mathrm{x} \pm \mathrm{SD}$ & $\min -\max$ & $\mathrm{CV}, \%$ & $\mathrm{x} \pm \mathrm{SD}$ & $\min -\max$ & $\mathrm{CV}, \%$ \\
\hline Body length, $\mathrm{mm}$ & $4.6 \pm 0.4$ & $3.94-5.12$ & 8.3 & $9.7 \pm 1.2^{* * * *}$ & $7.87-11.2$ & 12.2 \\
Maximum body width, $\mu \mathrm{m}$ & $257.4 \pm 17.8$ & $232-281$ & 6.9 & $546.2 \pm 37.1^{* * *}$ & $479-592$ & 6.8 \\
Length of spicule, $\mu \mathrm{m}$ & $119.9 \pm 12.9$ & $89-137$ & 10.8 & - & - & - \\
Length of longest tail part, $\mu \mathrm{m}$ & $221.2 \pm 35.2$ & $168-269$ & 15.9 & - & - & - \\
Distance from the vulva to the tail end, $\mu \mathrm{m}$ & - & - & - & $181.0 \pm 9.4$ & $161-194$ & 5.2 \\
Length of gonad eggs, $\mu \mathrm{m}$ & - & - & - & $0.10 \pm 0.01$ & $0.09-0.12$ & 10.2 \\
Width of gonad eggs, $\mu \mathrm{m}$ & - & - & - & $0.051 \pm 0.010$ & $0.042-0.059$ & 13.7 \\
\hline
\end{tabular}

Width of gonad eggs, $\mu \mathrm{m}$ 
The muscularis mucosae of the mucous membrane, especially between the intestinal glands, was swollen, i.e. was almost colourless, the collagen fibers were stretched and thinned-out (Fig. 6, 7). The edema processes were also found in the mucous membrane (Fig. 6). In some preparations we observed that the muscularis mucosae was notably infiltrated by lymphoid cells and histiocytes. High magnification revealed features of hypersecretion of slime in goblet cells of the intestinal glands in the form of accumulations of slime granules in cytoplasm, which poorly stained (Fig. 7). On the side of the muscular and serous membranes, no pathological changes were found.

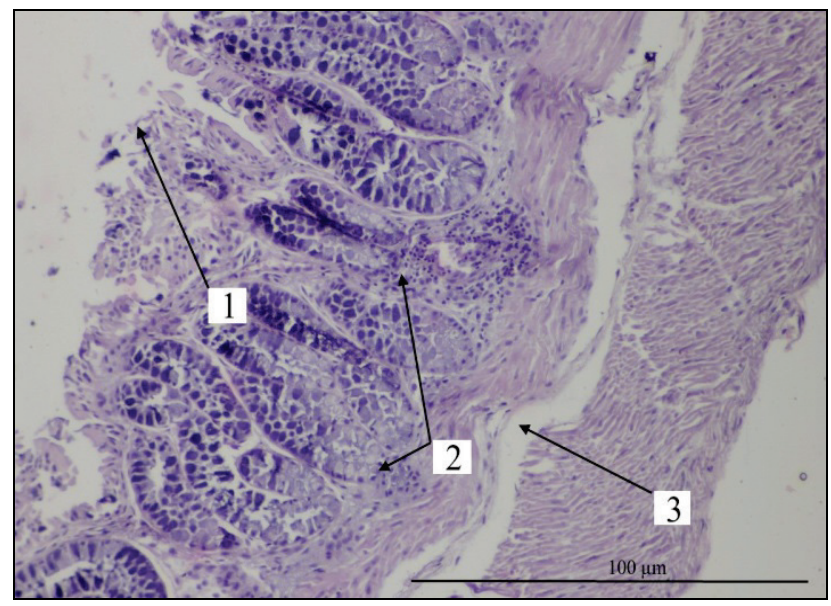

Fig. 5. Large intestine of an examined animal: destruction of the epithelium (1); lymphohistiocytic infiltration of the muscularis mucosae (2); edema of the tela submucosa (3); staining with Carazzi's hematoxylin and eosin

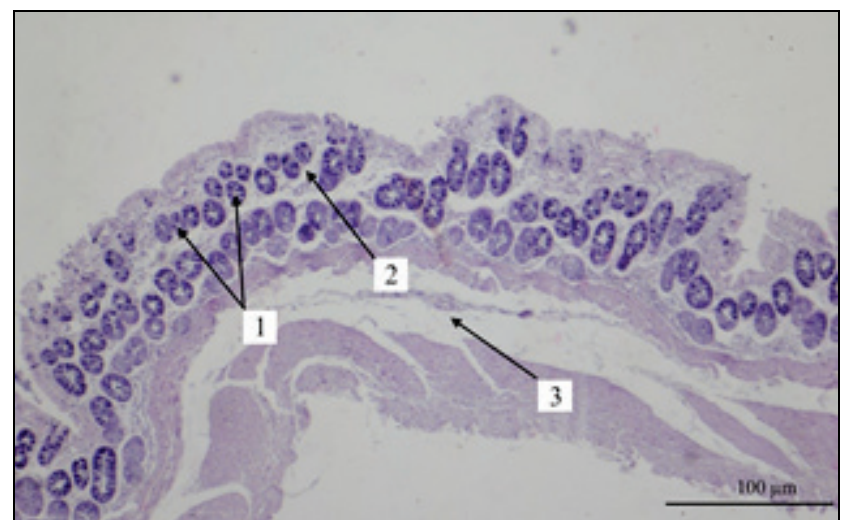

Fig. 6. The large intestine of an examined animal: intestinal glands (1); edema of muscularis mucosae (2) and tela submucosa (3); staining using Carazzi's hematoxylin and eosin

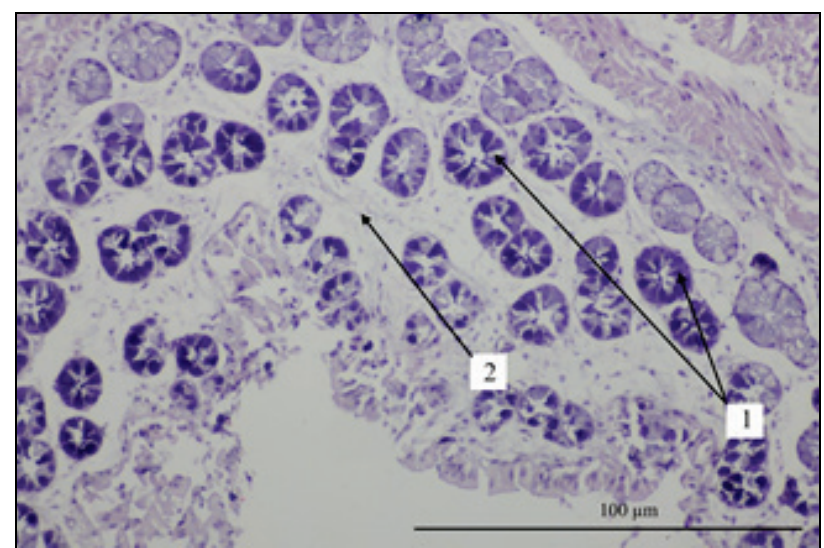

Fig. 7. The large intestine of an examined animal. Intestinal glands of basophilic colour of slime and secretion granules of goblet cells (1); edema of muscularis mucosae (2); staining using Carazzi's hematoxylin and eosin

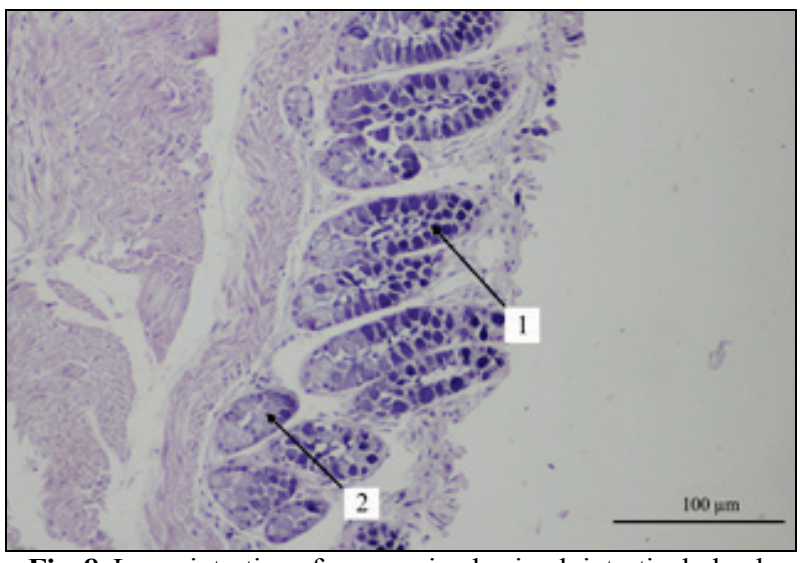

Fig. 8. Large intestine of an examined animal: intestinal glands with mostly basophilic (1) and transparent (2) slimy content of goblet cells (1); edema of muscularis mucosae (2); staining using Carazzi's hematoxylin and eosin

\section{Discussion}

Parasitism is one of antagonistic trophic relations in which an organism uses another species (host) as a temporary or constant place for living and source of nutrients. It completely depends on the host, negatively affects the host's condition, and can cause the host's death (Boyko et al., 2016). According to numerous studies, parasitoses contribute to development of somatic diseases, complications of chronic diseases, and affect the immune system. Characteristic of most helminths is the chronic course of the disease, related to the long term presence of the pathogen in the organism and possibility of repeating the infestation. At the same time, clinical features are manifested poorly, and pathological-anatomical changes are accompanied by productive processes which can practically change the functioning of part of the organ. A significant role in the pathogenesis of helminthoses is considered to be played by their mechanical impact conditioned by fixation of the parasites (using suckers, spikes, mouth capsules, cutting plates) and traumatization of the tissues or the host's organ, and is also related to the migration of larvae in the organism. During migration, nematode larvae synthesize enzymes which activate their penetration to their places of localisation. Accordingly Sharma et al. (2017) indicate that the lungs of domestic rabbits infested with Protostrongylus spp. had pathomorphologic changes characterized by notable thickening of the interstitium along with infiltration with the exudates which consisted of mononuclear cells and fibrins in certain places. At the same time, helminth larvae provide opportunities for penetration of infectious agents (Batte et al., 1977).

The species of nematode which we found is also distributed in the territories of other countries (Pinto et al., 2004; Rinaldi et al., 2007; Frank et al., 2013). However, the extent of description of this topic in different sources is not the same. Mostly, the presented data is focused on epizootopology (Eslampanah et al., 2014) and morphology of P. ambiguus, as described in scientific studies (Sheng et al., 2014; Sultan et al., 2015). We present the main parameters of $P$. ambiguus in conditions of the forest-steppe zone of Ukraine (Poltava Oblast) in seryi veleten breed rabbits. A number of scientists mention possible biological and morphological adaptative changes of nematodes, but up till now no parameters of the morphological structure of these nematodes in the territory of Ukraine have been described.

In the course of our research, we found helminths numbering from 46 to 142 specimens per host animal, their number varying depending on the sex of the host. Accordingly, male rabbits had fewer nematodes, and the ratio equaled 1.29. These data coincide with Elshahawy \& Elgoniemy (2018), who mention that females are more vulnerable to infestation than males. It was proved that sex is a determining factor which affects the prevalence of parasitism. According to Florian (1997), total infestation of females with helminths equals $67.2 \%$, and infestation of males $-57.2 \%$. According to our studies, infestation of female rabbits equaled $56.4 \%$, whereas in male rabbits $-43.6 \%$ of the total number of collected nematodes. 
In calculating the ratio of females and males of $P$. ambiguus in relation to the sex of the rabbits, we determined on average a different proportion of female and male nematodes, which we relate to the level of intensity of infestation. Thus, in the examined male rabbits, as we have mentioned before, the total number of nematodes was lower (73.8) compared to female rabbits (95.4). It should be mentioned that in cases of lower intensity of infestation, a higher number of female parasites was recorded. The ratio equaled 1.88 compared to 1.53 in female rabbits. This can be explained by the reproductive ability of females to provide maintenance of the species in the process of evolution. Thus, the number of nematodes conditions the extent of contamination of the environment with invasive elements.

As we know, the most important functions of the intestine are motor, secretion and resorption (absorbing) functions (Sicherer \& Sampson, 2010; Camps-Bossacoma et al., 2017). In the large intestine, the microflora have a special physiological function. It can perform various different functions: digestive, synthesizing and protective. Microflora takes active part in metabolism. Regulatory protection consists of formation and stimulation of the immune system. At the same time, it is responsible for coordination of the vegetative nervous system. The function of synthesis consists of biosynthesis of vitamins (thiamine $\left(\mathrm{B}_{1}\right)$, riboflavin $\left(\mathrm{B}_{2}\right)$, pantothenic $\left(\mathrm{B}_{3}\right)$ and folic acids $\left(\mathrm{B}_{\mathrm{c}}\right)$, niacin $(\mathrm{PP})$, biotin $(\mathrm{H})$, pyridoxine $\left(\mathrm{B}_{6}\right)$, phyllochinon $(\mathrm{K})$ ). But no less important protection is the obligatory microflora of the intestine, which inhibits the development of pathogenic microflora and becomes a natural sorbent by taking part in detoxification of xenobiotics (Mowat, 2003; Vighi et al., 2008; Camps-Bossacoma et al., 2017; Gavrylin \& Nikitina, 2017).

Under the impact of various endogenous causes, particularly parasites, composition of the intestinal microflora of animals, as the first line of the defense can change, causing disorders of normal courses of physiological processes. The second line is the mucous membrane, which also becomes affected by helminths. A number of authors mention that parasitism by Strongylidae in large ruminants causes formation of granuloma of different stages. And in the wall of the large intestine, we recorded infiltration of all layers of the mucous membrane by cells with domination of lymphocytes, and in the apical part and around the intestinal crypts, we observed with accumulation of granulocytes (eosinophils, neutrophils) and macrophages. At the same time, we observed accumulations of pus-necrotic inflammation. We found fragments of larvae of Oesophagostomum radiatum in the tela submucosa, which were surrounded by a large amount of lymphoid cells, granulocytes, and by a capsule on the outside. In such places, the intestinal wall was thickened (Kruchynenko et al., 2017).

The number of Ukrainian and Russian journals with studies on the impact of $P$. ambiguus on the organism of rabbits is low and outdated. The impact of this helminth on the physiological condition of animals has been described (Duda, 2017), while pathomorphological changes have been described only in scattered studies. Florian (1997) in his study mentions that the main structural changes manifest in the rabbits' large intestine. In the acute course ( $\mathrm{II}=9,257$ specimens) of the disease, in places where the parasites attach, the mucous membrane of the intestine was severely damaged. The most significant changes were recorded on the side of the crypts (glands of the mucous membrane). The epithelium beneath them was swollen; the nuclei had a rounded shape and were larger than normal size. In some places, diapedesis hemorrhges and insignificant accumulations (mostly singular) of polymorphonuclear leukocytes were diagnosed. Inflammatory edema in other layers of the intestinal wall was less significant. The authors consider the described changes as serous-catarrhal colitis.

In the course of our research on chronic passaluriasis, we diagnosed chronic catarrhal colitis with lymphohistiocytosis.

Scientists also have proved that in case of parasitism by intestinal helminths, the pathological picture is characteristic of catarrhal colitis with desquamation processes in the epithelium (Mohanta et al., 2007).

Researchers have found the following pathological changes in the histology of sheeps' cecum: infiltration by the lymphoid cells, eosinophils and fibroblasts around the body of the parasite Trichuris ovis (Iliev et al., 2017). These data were confirmed by other authors who determined similar pathomorphological changes in the cecum of rodents parasitised by Trichuris (Lopes Torres et al., 2011). The pathogenic impact of passaluriases is characterized by proliferation of goblet cells, desquamation of the epithelium of the intestine's mucous membrane, which is correlated with pathomorphological studies conducted on sheep with haemonchosis (Kumar et al., 2015).

\section{Conclusions}

In rabbits with chronic passaluriasis, a characteristic complex of pathomorphological changes develops. The examined animals were observed to have chronic catarrhal colitis with lymphohistiocytosis. The described changes in the large intestine develop as a result of the mechanical and inoculative effect of $P$. ambiguus parasites on the mucous membrane, and also as a result of the effect on it of substances produced by nematodes. The helminth affects the clinical course of the disease, and exacerbates the trophic damage to the host organism. Finding pathomorphological changes in rabbits with passaluriasis makes it possible to develop an efficient treatment orientated not only at the pathogen, but also at the organism in general, making the measures more effective, and the recovery faster. Prospects of using methods of post-mortem diagnostics allow one to control the extent of infestation on farms and implement measures against the parasites in good time.

We express gratitude for help in studying the nematode species and conducting morphometric studies to the Candidates of Biological Sciences O. B. Hreben and Y. Y. Syrota (Schmalhausen Institute of Zoology of National Academy of Sciences of Ukraine).

\section{References}

Batte, E. G., Mclamb, R. D., Muse, K. E., Tally, S. D., \& Vestal, T. J. (1977). Pathophysiology of swine trichuriasis. American Journal of Veterinary Research, 38, $1075-1079$.

Bordes, F., Langand, J., Feliu, C., \& Morand, S. (2007). Helminth communities of an introduced hare (Lepus granatensis) and a native hare (Lepus europaeus) in Southern France. Journal of Wildlife Diseases, 43(4), 747-751.

Boyko, O. O., Zazharska, N. M., \& Brygadyrenko, V. V. (2016). The influence of the extent of infestation by helminths upon changes in body weight of sheep in Ukraine. Biosystems Diversity, 24(1), 3-7.

Camps-Bossacoma, M., Perez-Cano, F. J., Franch, A., Untersmayr, E., \& Castell, M. (2017). Effect of a cocoa diet on the small intestine and gut-associated lymphoid tissue composition in an oral sensitization model in rats. Journal of Nutritional Biochemistry, 42, 182-193.

Duda, Y. V., Kunieva, L. V., \& Khrystian, O. P. (2017). Pokaznyky bilkovoho obminu kroliv za pasaluroznoi invazii [Indicators of protein metabolism of rabbits for pasaluronic invasion]. Science and Technology Bulletin of SRC for Biosafety and Environmental Control of AIC, 5(1), $93-96$ (in Ukrainian).

Edwards, E. E., Garner, B. C., Williamson, L. H., Storey, B. E., \& Sakamoto, K. (2016). Pathology of Haemonchus contortus in New World camelids in the southeastern United States: A retrospective review. Journal of Veterinary Diagnostic Investigation, 28(2), 105-109.

Eira, C., Torres, J., Miquel, J., \& Vingada, J. (2007). The helminth parasites of the wild rabbit Oryctolagus cuniculus and their effect on host condition in Dunas de Mira, Portugal. Journal of Helminthology, 81(3), 239-246.

Elshahawy, I., \& Elgoniemy, A. (2018). An epidemiological study on endoparasites of domestic rabbits (Oryctolagus cuniculus) in Egypt with special reference to their health impact. Sains Malaysiana, 47(1), 9-18.

Emerya, D. L., Huntb, P. W., \& Le Jambrec, L. F. (2016). Haemonchus contortus: The then and now, and where to from here? International Journal for Parasitology, 46(12), 755-769.

Eslampanah, M., Paykari, H., Moharami, M., Motamedi, G., \& Omraninava A. (2014). A survey on the gastrointestinal parasites of rabbit and guinea pig in a laboratory animal house. Archives of Razi Institute, 69(1), 77-81.

Fernández-Aguilar, X., Alzaga, V., Villanúa, D., Cabezón, O., García-Bocanegra, I., Dubey, J. P., \& Almería, S. (2013). Epidemiology and prevalence of Toxoplasma gondii infection in the Iberian hare (Lepus granatensis). Veterinary Parasitology, 196, 194-198.

Florian, D. D. (1997). Passaluroz krolikov v usloviyah Moskovskoy oblasti: Biologiya vozbuditelya, epizootologiya i meryi borbyi [Passalurosis of rabbits in the conditions of the Moscow region: Pathogen biology, epizootology and control measures]. Moscow (in Russian).

Frank, R., Kuhn, T., Mehlhorn, H., Rueckert, S., Pham, D., \& Klimpel, S. (2013). Parasites of wild rabbits (Oryctolagus cuniculi) from an urban area in Germany, in relation to worldwide results. Parasitology Research, 112, 4255-4266. 
Gavrylin, P. M., \& Nikitina, M. O. (2017). Morphometric parameters of the intestine and aggregated lymphatic nodules of meat rabbits. Regulatory Mechanisms in Biosystems, 8(4), 649-655.

Georgieva, K., Yoneva, A., Mizinska-Boevska, Y., \& Todev, I. (2005). Ultrastructure of the contact surfaces of Passalurus ambiguus (Rudolphi, 1819) (Nematoda). Acta Biologica Hungarica, 56(3-4), 297-303.

Goral's'kyj, L. P., Homych, V. T., \& Konons'kyj, O. I. (2005). Osnovy gistologichnoji tehniky i morfofunkcional'ni metody doslidzhen' u normi ta pry patologiji [Fundamentals of histological technique and morphofunctional methods of research in norm and in pathology]. Polissja, Zhytomyr (in Ukrainian).

Ilić, T., Stepanović, P., Nenadović, K., \& Dimitrijević, S. (2018). Improving agricultural production of domestic rabbits in Serbia by follow-up study of their parasitic infections. Iranian Journal of Veterinary Research, 19(4), 290-297.

Iliev, P. T., Ivanov, A., Kirkova, Z., Hristov, K., Dinkova, K., \& Ananiev, J. (2017) Some parasitological, pathological and immunohistochemical examinations in sheep naturally infected by Trichuris ovis. Trakia Journal of Sciences, 2, 174-178.

Jabbar, A., Campbell, A. J. D., Charles, J. A., \& Gasser, R. B. (2013). First report of anthelmintic resistance in Haemonchus contortus in alpacas in Australia. Parasites and Vectors, 6, 243

Kruchynenko, O. V., Skrypka, M. V., \& Panikar, I. I. (2017). Osoblyvosti patomorfolohichnykh zmin v stintsi kyshechnyku za shlunkovo-kyshkovykh stronhiliatoziv velykoi rohatoi khudoby [Features of the pathological changes in the intestinal wall at gastrointestinal strongylyatosis of cattle]. The Animal Biology, 19(2), 4449 (in Ukranian).

Kumar, S., Jakhar, K. K., \& Singh, A. D. (2015). Etio-pathological investigations to study the gross and histopathological lesions affecting gastrointestinal tract of sheep. Academic Journals, 10, 356-361.

Laakkonen, J., Nyyssönen, T., Hiltunen, M., Kauhala, K., Nikander, S., \& Soveri, T. (2006). Effects of Protostrongylus sp. and Pneumocystis sp. on the pulmonary tissue and the condition of mountain and brown hares from Finland. Journal of Wildlife Diseases, 42(4), 780-787.

Lello, J., Boag, B., \& Hudson, P. J. (2005). The effect of single and concomitant pathogen infections on condition and fecundity of the wild rabbit (Oryctolagus cuniculus). International Journal for Parasitology, 32, 1509-1515.

Lopes Torres, E. J., Nascimento, A. P. F., Menezes, A. O., Garcia, J., José dos Santos, M. A., Maldonado Jr., A., Miranda, K., Lanfredi, R. M., \& Souza, W. (2011). A new species of Trichuris from Thrichomys apereoides (Rodentia: Echimyidae) in Brazil: Morphological and histological studies. Veterinary Parasitology, 176, 226-235.

Mohanta, U. K., Anisuzzaman, A., Farjana, T., Das, P. M., Majumder, S. \& Mondal, M. M. H. (2007). Prevalence, population dynamics and pathological effects of intestinal helminths in black Bengal goats. Bangladesh Journal of Veterinary Medicine, 5, 563-569.

Mowat, A. M. (2003). Anatomical basis of tolerance and immunity to intestinal antigens. Nature Reviews Immunology, 3, 331-341.

Okumu, P. O., Gathumbi, P. K., Karanja, D. N., Mande, J. D., Wanyoike, M. M., Gachuiri, C. K., Kiarie, N., Mwanza, R. N., \& Borter, D. K. (2014). Prevalence, pathology and risk factors for coccidiosis in domestic rabbits (Oryctolagus cuniculus) in selected regions in Kenya. Veterinary Quarterly, 34(4), 205-210.

Ola-Fadunsin, S. D., \& Ibitoye, E. B. (2017). A retrospective evaluation of parasitic conditions and their associated risk factors in sheep and goats in Osun state, Nigeria. Sokoto Journal of Veterinary Sciences, 15(3), 15-24.
Ola-Fadunsin, S. D., Hussain, K., Rabiu, M., \& Ganiyu, I. A. (2018). Parasitic conditions of domestic owned rabbits in Osun State, Southwestern Nigeria: Retrospective evaluation, risk factors and co-infestations. International Journal of Veterinary Science and Medicine, 6(2), 208-212.

Pehlivanoğlu, B., Doğanavşargil, B., Sezak, M., Nalbantoğlu, İ., Korkmaz, M. (2016). Gastrointestinal parasitosis: Histopathological insights to rare but intriguing lesions of the gastrointestinal tract. Türkiye Parazitoloji Dergisi, 32(2), $82-90$.

Pinto, R. M., Gomes, D. C., Menezes, R. C., Gomes, C. T., \& Noronha, D. (2004) Helminths of rabbits (Lagomorpha, Leporidae) deposited in the helminthological collection of the Oswaldo Cruz Institute. Revista Brasileira de Zoologia, 21(3), 599-604.

Rewatkar, S. G., Deshmukh, S. S., Prem Kumar, G., Maske, D. K., \& Bhangale, G. N. (2013). Occurrence of gastrointestinal helminthes in rabbits with special reference to importance of Giardia spp. as parasitic zoonoses. Science, Technology and Arts Research Journal, 2(3), 142-143.

Rinaldi, L., Russo, T., Schioppi, M., Pennacchio, S., \& Cringoli, G. (2007). Passalurus ambiguus: New insights into copromicroscopic diagnosis and circadian thythm of egg excretion. Parasitology Research, 101(3), 557-561.

Rose, H., Hoar, B., Kutz, S. J., \& Morgan, E. R. (2014). Exploiting parallels between livestock and wildlife: Predicting the impact of climate change on gastrointestinal nematodes in ruminants. International Journal for Parasitology: Parasites and Wildlife, 15(2), 209-219.

Sharma, R., Kapoor, D., \& Kumar, R. (2017). A rare case of verminous pneumonia in domestic rabbit. Journal of Parasitic Diseases, 41(3), 716-717.

Sheng, L., Cui, P., Fang, S. F., Lin, R. Q., Zou, F. C., \& Zhu, X. Q. (2014) Sequence variability in four mitochondrial genes among rabbit pinworm (Passalurus ambiguus) isolates from different localities in China. The Journal of DNA Mapping, Sequencing, and Analysis, 26(4), 501-504.

Sicherer, S. H., \& Sampson, H. A. (2010). Food allergy. Allergy and Clinical Immunology, 125, 116-125.

Sultan, K., Elhawary, N. M., Sorour, S. S. G., \& Sharaf, H. M. (2015). Observations of the rabbit pinworm Passalurus ambiguus (Rudolphi, 1819) in domestic rabbits (Oryctolagus cuniculus) in Egypt using a scanning electron microscope. Tropical Biomedicine, 32(4), 745-752.

Sürsal, N., Gökpinar, S., \& Yildiz, K. (2014). Prevalence of intestinal parasites in hamsters and rabbits in some pet shops of Turkey. Türkiye Parazitoloji Dergisi, 38(2), 102-105.

Szkucik, K., Pyz-Łukasik, R., Szczepaniak, K. O., \& Paszkiewicz, W. (2014). Occurrence of gastrointestinal parasites in slaughter rabbits. The Journal Parasitology Research, 113(1), 59-64.

Vighi, G., Marcucci, F., Sensi, L., Di Cara, G., \& Frati, F. (2008). Allergy and the gastrointestinal system. Clinical and Experimental Immunology, 153, 3-6.

Yevstafieva, V. A., Yeresko, V. I., Pishchalenko, M. A., \& Nagorna, L. V. (2018) Differential species characters of Baruscapillaria anseris and B. obsignata nematodes obtained from the domestic goose. Regulatory Mechanisms in Biosystems, 9(4), 578-583.

Yevstafieva, V. A., Melnychuk, V. V., Nikiforova, O. V., Suprunenko, K. V., Korchan, L. N., Lokes-Krupka, T. P., Nehrebetskyi, I. S., \& Korchan, N. I. (2018). Comparative morphology and biology of nematodes of genus Heterakis (Nematoda, Heterakidae), parasites of the domestic goose (Anser anser). Regulatory Mechanisms in Biosystems, 9(2), 229-236.

Zon, H. A., (2005). Patolohichna anatomiia parazytarnykh khvorob tvaryn [Pathological anatomy of parasitic animal diseases]. Dzherelo, Sumy (in Ukrainian). 